pages. I ower mean temperatures of particular months have occurred previously in Shetland, Orkney, and the extreme north of Caithness and Sutherland, January, 1867, having been colder in these northern regions. Other months, notably February, 1855, were as cold as, or colder than, January last over England generally except its north-western counties. But in this latter district and over the whole of the rest of Scotland January was colder than any month on record, yoing back for the different districts on observation; which extend over periods varying from 24 to II 8 years. The mean temperature fell below that of any previously recorded month in varied amounts up to $4^{\circ} \mathrm{O}$, this excessive degree of cold being experienced chiefly in the upper narrow valleys of the interior of the country, such as Lairs in Sutherland, Upper Deeside, and Tweeddale, and the uplying valleys of the Cheviots. The greatest absolute cold occurred on the nights immediately preceding the great London storm of the 18 th, the lowest, so far as the facts have reached us, being - $16^{\circ} \circ \mathrm{O}$ near Kelso; $-15^{\circ} \circ \mathrm{O}$ at Stobo Castle in Peeblesshire; - I $3^{\circ} \mathrm{O}$ at Paxton House near Berwick; - $\mathbf{I} \mathbf{I}^{\circ} \mathrm{O}$ at Lairg, and Thirlestane Castle near Lauder; and $-8^{\circ} \cdot 0$ at Milne Graden near Coldstream. This depression of temperature thus equalled that of the memorable night of December 4,1879 , when it fell, at Springwood Park near Kelso, to - $16^{\circ} \circ$, which is abso lutely the lowest authentic temperature that has been recorded in Great Britain since thermometers came into use, leaving out of view as incomparable and misleading all observations made with exposed thermometers. In Scotland, the mean temperature of each of the five months ending with February was under the average, the depression being greatest just where as stated above the cold of January was greatest. The mean temperature of these five months was $5^{\circ} .6$ under the average in West Perthshire, $5^{\circ} \cdot 0$ at Lanark, $4^{\circ} \cdot 5$ at Thirlestane Castle, Braemar, and Culloden, and about $3^{\circ} \mathrm{O}$ in the west from North Unst to the Solway Firth. In South Britain, the mean temperature of this period did not fall so low owing to the milder weather there during November and Decenber. The snowstorms of this winter are, at least equally memorable, particularly the great storin of the third week of January in the south of England, and the great storm in Scotland in the first week of Marcb, when railway traffic was paralysed, many trains being buried under snow-wreaths, twenty, thirty, and even in some cases forty feet in thickness.

\section{THE OXFORD UNIVERSITY COMMISSIONERS AND THE PROFESSORIATE}

THE University Commissioners have $\mathrm{i}$-sued a revised edition of the proposed statute; on the professoriate. The scheme laid before the Hebdomadal Council last November met with considerable opposition, which re ulted in representations bein made by the Council to the Commissioners in favour of certain modifications in the duties assigned to the professors. On comparing the revised with the old proposals, it is evident that the Commissioners have become convinced that it is desirable to allow each professor a larger individual Jiberty in the mode of giving instruction in his department than was granted in the former scheme. In the General Regulations of last November Clauses 4 and 5 ran as follows:-

4. During the period of each term over which his course of lectures shall extend, and on so many days in the week as the particular regulations applicable to his chair require, he shall be ready to give private instruction to such students, being member of the university and attending his lectures, as may desire to receive it, in such matters relevant to the subjects of his lectures as may more conveniently be explained in that monner, and also to test by questions or otherwise, as may be convenie.ut, the knowledge of such students in those subjects. Such private instruction shall be open without fee to students who are members of a college out of the rcvenues of which his chair is wholly or partly endowed, and to other students on payment of such fees (if any) as the professor may require, not exceeding in number or amount the limit set by any statutes of the university in that behalf which may be in force for the time being.

5. At the end of each term in which he has delivered lectures he shall examine the students who have attended them, and shall, on the request of the head of any college, inform the college of the results of the examination as regards the student who are members of such college, and shall also, if requested, give like information to the Delegates of students not attached to any college or hall.

In the new statutes the obligation to examine the whole class is removed; but each professor at the head of a laboratory or observatory must inform the college authorities of the regularity and proficiency of students attending his department. The new general regulations run as follow:-

\section{Duties of Professors}

I. It shall be the duty of every professor in his de artment to give instruction to students, assist the pursuit of knowledge, and contribute to the advancement of it, and aid generally the work of the university.

2. Every professor shall in respect of the lectures to be given by him conform to the particular regulations applicable to his chair. He may lecture in such manner and form as he judges to be hest for the instruction of students and the advancement of knowledge.

3. It shall be his duty to give to students attending his ordinary lectures assistance in their studies by advice, by informal instruetion, by occasional or periodical examination, and otherwise, as he may jud ge to be expedient. For receiving students who desire such assistance he shall appoint stated times in every week in which he lectures.

4. At the reques: of any student who has regularly attended any course of lectures he shall certify in writing the fact of such attendance.

5. The ordinary lectures of every professor shall be open to all students who are members of the university without payment of any fee, unles; the university shall otherwise determine. But the university may, if it should deem it expedient so to do, by statute or decree authorise any professor to require payment of fees not exceeding a specified amount in respect of all or any of bis lectures or of the instruction to be given by him.

6. Every professor shall in addition to his ordinary lectures deliver from time to time, after previous public notice, a public lecture or lectures to be open to all members of the university without payment of any fee.

With regard to the manner of election to professorships and to the dispensations and leave of absence granted by the visita torial boards, little or no alterations have been made. The professoriate is divided into three schedules. With the exception of the professors of geology, mineralogy, and botany who come under Schedule B, the pr.jessors in the different departments of natural science come under Schedule $C$, to which division the following particular regulations are applicable :-

(a) The professor shall reside within the university during six months at least in each academical year, between the first day of September and the ensuing first day of July.

(b) He shall lecture in two at least of the three university terms. His lectures shall extend over a period not less in any term than six weeks, and not less in the whole than fourteen weeks, and he shall lecture twice at least in each week.

(c) The laboratory under the charge of each professor, and in the case of the Savilian Professor of Astronomy, the University Observatory, shall be open for eight weeks in each term, and at such other times and for such hours as the university may by statute determine.

Students shall be admitted to the university observatory, and to the laboratory under the charge of each professor, upon such conditions as the university shall from time to time by statute determine, and upon the terms of paying such fees, not exceeding such amount as may be fixed by any statute of the university in force for the time being, as the professor may from time to time require.

(d) Except for some grave reason to be approved by the Vice-Chancellor, the professor shall, for seven weeks in each term, and during some part of three days in each week, be ready to give instruction in the subject of his chair to such students as shall have been ad nitted to the laboratory under his charge (or in the case of the Savilian Professor of Astronomy, to the University Observatory); and such instruction shall be given in the laboratory or observatory (as the case may be) or in some class-room connected therewith.

(c) The professor shall also, at the close of each term, inform any college which may request him to do so as to the regularity of attendance and the proficiency of the students belonging to such college who have been admitted into the laboratory or observatory under his charge, and shall give like information, if requested, to the Delegates of students $\mathrm{n}$ )t attached to any college or hall.

4. The particular regulations next following shall be applicable to the several professors named in them re ipectively (that is to say) - 
(a) The Savilian Professor of Astronomy shall have the charge of the University Observatory, and shall undertake the personal and regular supervision of the same, and of the several demonstrators and other assistants employed therein, and shall be responsible for all the work carried on there.

(b) The Professor of Experimental Philosophy shall have the charge of the Clarendon Laboratory, and shall undertake the personal and regular supervision of the same, and of the several demonstrators and other assistants employed therein, and shall be responsible for all the work carried on there.

(c) The Waynflete Professor of Chemistry shall have the charge of the chemical laboratories in the University Museum, or such part thereof as the university may by statute assign to him, and shall undertake the personal and regular supervision of the same, and of the several demonstrators and other assistants employed therein, and shall be responsible for all the work carried on there.

(d) The Linacre Professor of Human and Comparative Anatomy shall have the charge of the anatomical and ethnological collections and the anatomical laboratories in the University Museum, or such part thereof as the university may by statute assign to him; and shall undertake the personal and regular supervision of the same and of the several demonstrators and other assistants employed therein, and shall be responsible for all the work carried on there.

(e) The Professor of Botany and Rural Economy shall have the charge and supervision of the Botanical Gardens and botanical collections belonging to the university; and it shall be part of his duty to make such gardens and collections accessible to, and available for the instruction of, students attending his lectures.

(f) The Professors of Geology and Mineralogy respectively shall have the charge and supervision of the geological and palæontological collections and of the mineralogical collection belonging to the aniversity; and it shall be part of their duties to make such collections respectively accessible to, and available for the instruction of, students attending their lectures.

To the class of teachers to be called University Readers some of the duties assigned to the professoriate under the old scheme are now transferred. The "informal instruction" twice a week to all students who may demand it becomes now part of the regular duty of the Reader, and not of the Professor. The following are the most important clauses on University Readers :-

(a) Every appointment of a University Reader shall be made by the Delegates of the Common University Fund, or by persons, not fewer than three in number, nominated for that purpose by the Delegates.

(b) Every University Reader shall hold his office for five years, but shall be re-eligible.

(c) He shall receive from the Common University Fund $300 \mathrm{co}$ per annum.

(d) He shall in every year lecture in each of the three University Terms (Easter and Trinity Terms being counted as one). His lectures shall extend over a period not less than seven week in each term, nor than twenty-one weeks in the whole, and he shall lecture twice at least in each week. In addition to these lectures he shall, twice at least in every week in which he lectures, receive students desirous of informal instruction and other assistance in the studies with which his readership is connected.

(e) He may require from students receiving the informal instruction and assistance mentioned in the foregoing regulation payment of a fee not exceeding $2 l$. for any university term. With this exception his lectures shall be open to all members of the university without payment of any fee.

5. It shall be the duty of every reader to lecture and give instruction in the subject or branch of study for which he is appointed, and in arranging the subjects and times of his lectures it shall also be his duty to have regard to the arrangements made or proposed to be made by the professors, if any, lecturing in the same department of study.

The most important change in the new scheme is the liberation of the professor and reader from the immediate control of the council or board of his faculty. Under the old scheme each professor and reader was obliged during Easter term to send in to the faculty a schedule of all his lectures and other instruction for the ensuing year, giving the days, hours, and subjects of the lectures. 'The faculty was to have the power of criticising the schedules and of recommending alterations, and the two following clauses were intended to reduce a refractory professor to submission :-
14. The Council shall not aiter any schedule without the consent of the person named in it. But if a recommendation made by the Council as to any schedule be not acceded to, the Council may, if they think fit, exclude the schedule or the part of it affected by such recommendation from the list, unless such schedule was sent in by a Professor or University Reader. In the last-mentioned case the Council shall not exclude the schedule, but may, if they think fit, report the fact to the Vice-Chancellor, who shall lay the report before the Visitatorial Board.

I5. If a Professor or University Reader wilfully neglect to send in schedules of his lectures, the Visitatorial Board may, on a report of the Council of the Faculty, and without any charge laid before the board, proceed against him by admonition or otherwise as for a neglect of the duties of his office. Refusal on the part of a Professor or University Reader to accede to any recommendation of the Council of his faculty respecting his lectures may likewise be treated by the board as a neglect of duty, if, on a consideration of the circumstances, the board be satisfied that such refusal was without reasonable justification. Provided that if the recommendation relate to the subjects of the proposed lectures it shall be sufficient for the Professor or University Reader to show that such lectures are in respect of their subject-matter a bonâ fide fulfilment of the statutory duties of his office.

The following are the new clauses which regulate the relation between the professoriate and the board in the different faculties of arts, theology, law, and natural science :-

The board of each faculty shall have the following duties and powers :-

It shall be the duty of the board to prepare and send to the Vice-Chancellor for publication-

(a) Before the end of each term a list of the lectures which are to be given in the ensuing term in the subjects of the faculty under the authority of the university or of any college, or of the Delegates of students not attached to any college or hall, and are to be open to persons other than the members of any one college, or (as the case may be) other than the students not attached to any college or hall.

(b) In Easter or Trinity Term annually a general scheme or statement showing, as far as may be, the lectures to be given as aforesaid during the course of the ensuing academical year.

(c) In Michaelmas Term, or at such other time in each year as the university may by statute appoint, a summary statement of the lectures given during the preceding year in the subjects of the faculty by Professors and University Readers, and of all other lectures which have been advertised in the published lists of the faculty and given in conformity therewith. The board shall add to this statement such further information (if any) respecting the studies and instruction of the faculty as the university may by statute require, and may point out any deficiencies in the provision made for instruction, and make recommendations for supplying them.

I0. It shall be the duty of every Professor and University Reader to send to the Secretary of the Boards of Faculties timely notice of the lectures he proposes to give in any of the subjects of any faculty to which he belongs, purstiant to the statutes and regulations in force for the time being, and in arranging his lectures to have due and reasonable regard to the recommeildations of the board of the faculty; but this duty shall not be deemed to preclude him from the free use of his discretion in selecting for his lectures any subject or part of a subject which he deems most advisable within the province assigned to him by statute.

\section{GOLD IN NEWFOUNDLAND}

REPORTS having been circulated for some time past that gold had been discovered in quartz veins in the regions near Brigus of Conception Bay, Newfoundland, Mr. Murray has recently made a personal examination of the ground.

In his report to the Governor of the Colony, dated October 8 , he states that by the first blast from two to three cubic feet of rock were removed, all of which was carefully broken up, washed, and examined; which operation finally resulted in the display of ten or twelve distinct "sights" of gold. In one fragment about five pounds weight, largely charged with dark green chlorite, the gold shows itself in three places distinctly, while many small specks are perceptible by means of a good lens. The fracture of a fragment of milky white and translucent 